\title{
A juvenilis és felnőttkori dermatomyositises betegek klinikai jellemzői
}

\author{
Szalmás Orsolya dr. - Nagy-Vince Melinda dr. \\ Dankó Katalin dr. - Farkas Flóra dr.
}

Debreceni Egyetem, Klinikai Központ, Általános Orvostudományi Kar, Belgyógyászati Intézet, Klinikai Immunológiai Tanszék, Debrecen

\begin{abstract}
Bevezetés: A juvenilis és felnőttkori dermatomyositisek szisztémás autoimmun megbetegedések, jellegzetességük a proximális végtagizomzat szimmetrikus gyengesége és típusos bőrtünetek megjelenése. Célkitüzés: A felnőttkori, illetve gyermekkori dermatomyositises betegek összehasonlítása tüneteik, laboratóriumi és immunszerológiai paramétereik, terápiára adott válaszuk, illetve kórlefolyásuk alapján. Módszer: A szerzők a vizsgálatban részt vevő betegek klinikai dokumentációinak retrospektív elemzésével összehasonlították a juvenilis és felnőttkori dermatomyositises betegcsoportokat a célkitüzésben megadott szempontok alapján. A kutatásba 27 juvenilis (átlagéletkor: 8,7 év, átlagos követési idő: 104,6 hónap) és 30 felnőttkori (átlagéletkor: 50,3, átlagos követési idő: 58,1 hónap) dermatomyositises beteget vontak be. Eredmények: A juvenilis dermatomyositises betegek között gyakrabban került sor cyclosporin A és intravénás immunglobulin alkalmazására. A felnőtt korú betegek között az akut betegségkezdet gyakrabban fordult elő. Gyermekekben a tünetek fokozatosan jelentkeznek. Köpetkeztetések: A szerzők eredményei egyeznek a szakirodalomban leírtakkal. Megfigyeléseik szerint a két alcsoport klinikailag és terápiás szempontból is különbözik. Betegeik rendszeres gondozása a remisszió elérése után is szükséges - elkerülve ezzel a rossz betegcompliance-t -, ezáltal csökkenthetô a relapsusok száma és súlyossága. Orv. Hetil., 2015, 156(37), 1491-1496.
\end{abstract}

Kulcsszavak: klinikai immunológia, dermatomyositis, juvenilis, calcinosis cutis, intravénás immunglobulin

\section{Clinical features of patients with juvenile and adult dermatomyositis}

Introduction: Juvenile and adult dermatomysitis are chronic, immune-mediated inflammatory myopathies characterized by progressive proximal muscle weakness and typical skin symptoms. Aim: To compare the symptoms, laboratory and serological findings, treatment and disease course in children and adults suffering from dermatomyositis. Method: In this retrospective study, juvenile and adult dermatomyositis groups were formed. There were 27 patients with juvenile dermatomyositis (mean age, 8.7 years; mean follow-up time: 104.6 months) and 30 adult patients (mean age, 50.3; mean follow-up time: 58.1 months). Results: In patients with juvenile dermatomyositis, treatment with intravenous immunoglobulin and cyclosporine A were more frequent as compared to adult patients. Acute onset of the disease was more frequent in adult patients than in those with juvenile disease. In children symptoms of the disease developed gradually. Conclusions: The findings confirm previously published data showing that there are differences between juvenile and adult patients with dermatomyositis. The authors recommend to follow the patients regularly after reaching remission to avoid bad patient compliance and decrease the number and severity of relapses.

Keywords: clinical immunology, dermatomyositis, juvenile, calcinosis cutis, intravenous immunoglobulin

Szalmás, O., Nagy-Vince, M., Dankó, K., Farkas, F. [Clinical features of patients with juvenile and adult dermatomyositis]. Orv. Hetil., 2015, 156(37), 1491-1496.

(Beérkezett: 2015. május 18.; elfogadva: 2015. június 30.) 


\section{Rövidítések}

ANA $=$ antinukleáris antitest $; \mathrm{CK}=$ kreatinkináz; $\mathrm{DM}=$ dermatomyositis; EMG = elektromiográfia; GOT = glutamátoxálecetsav-transzamináz; GPT = glutamát-piroszőlősavtranszamináz; IL = interleukin; IVIG $=$ intravénás immunglobulin; IIM = idiopathiás inflammatorikus myopathia; JDM = juvenilis dermatomyositis; $\mathrm{LDH}=$ laktátdehidrogenáz; MAA $=$ myositisasszociált antitest $;$ MSA $=$ myositisspecifikus antitest; RF = reumafaktor; TNF- $\alpha=$ tumornekrózis-faktoralfa; $\mathrm{We}=$ Westergreen-érték (vérsejtsüllyedés)

A juvenilis és felnőttkori dermatomyositis az idiopathiás inflammatorikus myopathiák (IIM) közé tartozó szisztémás autoimmun betegségek alcsoportjai, amelyek közös jellegzetessége a harántcsíkolt izomzat immunmediált gyulladása, amely progresszív izomgyengeséghez vezet, elsősorban a proximális végtagizmokban. Emellett típusos bőrtünetek megjelenésére is számíthatunk.

Az IIM-ek csoportjába ritka és igen heterogén kórképek tartoznak, emellett gyakran jelentkezik kevésbe típusos formában, ezért nem egyszerü felismerni a betegséget. A betegség kezelésében és a prognózis befolyásolásában a legfontosabb tényezô az időben elkezdett glükokortikoidterápia, amelyhez elengedhetetlen a kórkép korai felismerése. Az elsőként választandó kortikoszteroidok mellett alkalmazhatunk még másodvonalbeli immunszuppresszív szereket (cyclosporin A, methotrexat, cyclophosphamid, azathioprin), intravénás immunglobulint, valamint „biológiai terápiás” készítményeket, például rituximabot $[1,2]$. A betegség lefolyása szempontjából 4 kórformát különböztetünk meg: monofázisos-akut (egy aktív periódus után a kezelés mellett a beteg panaszmentes, a tünetek azonban 1 héten belül jelentkeznek), monofázisos-szubakut (a tünetek lappangva, több mint 1 hét alatt alakulnak ki), polifázisos (adekvát terápia mellett is a relapsusok és remissziók váltakoznak, gyakran van szükség terápiamódosításra), krónikus progresszí (a kombinált immunszuppresszív terápia ellenére is fokozatosan romlik a beteg állapota) [3]. Az utóbbi két kórlefolyás esetében az alapbetegség aktivitása mellett a hosszú távú szteroid- és immunszuppresszív kezelés mellékhatásaira is figyelnünk kell. Ezért kiemelkedő jelentőségű a korai diagnózis és az is, hogy a myositises betegek gondozása az IIM-ek kezelésében nagy tapasztalattal rendelkező immunológiai centrumokban történjen.

A diagnózis alappilléreit Bohan és Peter kritériumrendszere adja meg, amely a következő:

1. A proximális végtagizmok szimmetrikus gyengesége.

2. Jellegzetes szövettani eltérések a harántcsíkolt izmokban.

3. Az izomenzimek (elsősorban a $\mathrm{CK}$, valamint az aldoláz, GOT, GPT, LDH) szérumszintjének emelkedése.

4. Specifikus elektromiográfiás (EMG) eltérések (kis amplitúdójú, polifázisos hullámok; magas frekvenciájú tüskék; spontán fibrilláció és pozitív meredek hullámok).
5. Karakterisztikus bőrtünetek (heliotrop rash, Gottron-jel és Gottron-papula, V-jel) jelenléte DM esetén $[4,5]$.

A laboratóriumi vizsgálatok során az izomenzimek szérumszintjének emelkedését észlelhetjük. Az aktív szakban az emelkedett kreatinkináz- (CK-) érték a betegek 90\%-ában megfigyelhető. A szérum-laktátdehidrogenáz (LDH), -glutamát-oxálecetsav-transzamináz (GOT), -glutamát-piroszőlősav-transzamináz (GPT) és az aldolázaktivitás is emelkedett lehet. Az egyéb laboratóriumi értékek közül a gyulladás nem specifikus jelei is kórjelzőek lehetnek: a gyorsult süllyedés (We), az emelkedett CRP, a mérsékelt leukocytosis és thrombocytosis. Jellegzetesek lehetnek az immunszerológiai eltérések is, myositisspecifikus és myositisasszociált autoantitestek (MSA, MAA) 40-60\%-ban, az antinukleáris antitest (ANA) 50-90\%-ban, a reumafaktor (RF) 10\%-ban pozitív [6]. A szerológiai eltérések meghatározása segíti a diagnózis felállítását, a prognózis megítélését és a megfelelő terápia kiválasztását $[7,8]$.

Vizsgálatunk célkitűzése az volt, hogy összehasonlítsuk a juvenilis és felnőttkori dermatomyositises betegeket a tüneteik, laboratóriumi és immunszerológiai eredményeik alapján. Továbbá összevetettük a két betegcsoportot a betegség lefolyása során alkalmazott immunmoduláns terápia és az ezekre adott terápiás válasz alapján. Vizsgáltuk az egyes kórlefolyástípusok megjelenési gyakoriságát, valamint a relapsusok jelentkezésének idejét és gyakoriságát.

\section{Módszer}

Vizsgálatunk során a Debreceni Egyetem, Klinikai Központ, Belgyógyászati Intézet myositis-szakrendelése által gondozott 57 DM-es beteg adatát dolgoztuk fel. Két betegcsoportot alakítottunk ki: az egyik egy 27 fóból álló juvenilis DM-es csoport, amelynek átlagéletkora a diagnózis felállításakor 8,7 (szórás: $\pm 4,2$ ) év volt. A legfiatalabb gyermek 4 éves volt, míg a legidősebb 17 éves. E betegek diagnózisának felállítása 1972 és 2011 között történt. Az átlagos követési idejük pedig 104,63 hónap. A másik betegcsoportba 30 felnőtt korú DM-es páciens tartozott, akiknél a diagnózis felállítása 1999 és 2011 között valósult meg. Átlagéletkoruk a diagnózis idején 50,3 (szórás: $\pm 16,2$ ) év volt. Ebben a betegcsoportban a legfiatalabb egyén 21 éves volt, míg a legidősebb 67 éves. A páciensek átlagos követési ideje 58,10 hónap volt. A nemek aránya a gyermek és felnőtt korú betegek esetében nem különbözik 1:2,3 (JDM-ben 8 fiú és 19 lány, DM-ben 9 férfi és 21 nő).

A klinikai adatok áttekintését retrospektív módszerrel végeztük a klinikai adatbázis segítségével. A csoportok közti különbségek, így a tünetek, laboratóriumi értékek, immunszerológiai paraméterek összehasonlítására Pearson-féle $\chi^{2}$-próbát, Mann-Whitney- és Fisher-tesztet alkalmaztunk. A szignifikáns eltérés statisztikai küszöbe 
1. táblázat

A vizsgált tünetek, laboratóriumi és immunszerológiai paraméterek

\begin{tabular}{|c|c|c|}
\hline Tünetek & Laboratóriumi értékek & $\begin{array}{l}\text { Immunszerológiai } \\
\text { leletek }\end{array}$ \\
\hline $\begin{array}{l}\text { Proximális } \\
\text { izomgyengeség, } \\
\text { proximális } \\
\text { izomérzékenység, } \\
\text { proximális } \\
\text { izomatrophia, } \\
\text { heliotrop rash, } \\
\text { Gottron-jel, } \\
\text { Gottron-papula, } \\
\text { sáljel, V-jel, } \\
\text { periorbitalis oedema, } \\
\text { extensor erythema, } \\
\text { calcinosis cutis, } \\
\text { periungularis } \\
\text { teleangiectasia, } \\
\text { mechanikus kéz, fény } \\
\text { okozta erythema, } \\
\text { poikiloderma, } \\
\text { arthritis, } \\
\text { polarthralgia, } \\
\text { cutan vasculitis, } \\
\text { Raynaud-jelenség, } \\
\text { láz, ILD, } \\
\text { contractura, } \\
\text { dysphagia }\end{array}$ & $\begin{array}{l}\text { Kreatinkináz }(\mathrm{CK}) \text {, } \\
\text { laktátdehidrogenáz } \\
\text { (LDH), glutamát- } \\
\text { oxálacetát- } \\
\text { transzamináz (GOT), } \\
\text { glutamát-piruvát- } \\
\text { transzamináz (GPT), } \\
\text { vértest-süllyedés } \\
\text { (We), C-reaktív } \\
\text { protein }(\mathrm{CRP})\end{array}$ & $\begin{array}{l}\text { Myositisspecifikus } \\
\text { antitestek (MSS): } \\
\text { anti-Jol, anti-PL7, } \\
\text { anti-PL12, anti-SRP, } \\
\text { anti-Mi2, anti-OJ, } \\
\text { anti-EJ } \\
\text { Myositisasszociált } \\
\text { antitestek (MAA): } \\
\text { anti-U1-RNP, } \\
\text { anti-PmScl, anti-Ku, } \\
\text { anti-Sm/RNP, } \\
\text { anti-Ro60, anti-RNS, } \\
\text { anti-Scl-70, } \\
\text { anti-SS-A, anti-SS-B, } \\
\text { anti-rRNP, } \\
\text { anti-Ro52, } \\
\text { anti-DNS }\end{array}$ \\
\hline
\end{tabular}

p<0,05 volt. Az így kapott eredményeket pedig összevetettük a szakirodalomban korábban leírtakkal.

A vizsgált tüneteket, laboratóriumi és immunszerológia paramétereket az 1. táblázat tartalmazza.

\section{Eredmények}

A követési idő alatt azt tapasztaltuk, hogy a JDM-es betegek között a leggyakrabban megjelenő tünetek a proximális izomgyengeség $(25 / 27 ; 92 \%)$, izomérzékenység $(21 / 27 ; 77 \%)$, heliotrop rash $(18 / 27 ; 66 \%)$ és Gottron-papula $(15 / 27 ; 55 \%)$. A felnőttek esetén az izomgyengeség 100\%-os elöfordulást mutatott (30/30), ezenkívül az izomérzékenység $(18 / 30 ; 60 \%)$, heliotrop rash $(20 / 30 ; 70 \%)$, Gottron-papula $(16 / 30 ; 53 \%)$, polyarthralgia $(13 / 30 ; 43 \%)$ és Raynaud-jelenség $(14 / 30$; $46 \%$ ) fordult elő legtöbbször.

Statisztikai számításaink során szignifikáns különbségeket tapasztaltunk a két betegcsoport között egyes tünetek előfordulásában. A calcinosis cutis $(\mathrm{p}=0,008)$ és az izomatrophia ( $\mathrm{p}=0,011)$ JDM-es betegek között szignifikánsan gyakrabban fordult elő. Felnőttkori DMben a mechanikus kéz $(p=0,012)$, a poikiloderma $(\mathrm{p}=0,005)$, a $\mathrm{V}$-jel $(\mathrm{p}=0,001)$ és a Raynaud-jelenség $(\mathrm{p}=0,054)$ megjelenése gyakoribb a gyermekekhez képest. Calcinosis cutis felnőtt betegeink esetében nem alakult ki.

A juvenilis és a felnőttkori DM-ben szenvedő betegek klinikai jellemzői (bőrtünetek, az extramuscularis és extraskeletalis szövődmények gyakorisága) megfelelnek a
2. táblázat $\mid$ A juvenilis dermatomyositisben szenvedő gyermekek klinikai jellemzői a szakirodalmi adatokkal összevetve

\begin{tabular}{lccc}
\hline Tünetek & $\begin{array}{c}\text { Saját adatok } \\
(\mathrm{n}=27)\end{array}$ & $\begin{array}{c}\text { Pachman } \\
(\mathrm{n}=79)\end{array}$ & $\begin{array}{c}\text { Shehata } \\
(\mathrm{n}=25)\end{array}$ \\
\hline Izomgyengeség & $92 \%$ & $100 \%$ & $100 \%$ \\
Izomérzékenység & $77 \%$ & $73 \%$ & $56 \%$ \\
Heliotrop rash & $66 \%$ & $100 \%$ & $52 \%$ \\
Láz & $29 \%$ & $65 \%$ & $56 \%$ \\
Arthritis, polyarthralgia & $18 \%, 27 \%$ & $35 \%$ & $64 \%, 68 \%$ \\
Gottron-papula & $55 \%$ & - & $60 \%$ \\
Calcinosis cutis & $22 \%$ & $23 \%$ & $40 \%$ \\
ILD & $3 \%$ & - & $48 \%$ \\
Dysphagia & $18 \%$ & $44 \%$ & $76 \%$ \\
\hline
\end{tabular}

3. táblázat |A felnőttkori DM-es betegek klinikai jellegzetességeinek összevetése a nemzetközi irodalommal

\begin{tabular}{lcc}
\hline Tünetek & $\begin{array}{c}\text { Saját adatok } \\
(\mathrm{n}=30)\end{array}$ & $\begin{array}{c}\text { Koh } \\
(\mathrm{n}=75)\end{array}$ \\
\hline Proximális myopathia & $80 \%$ & $86 \%$ \\
Arthralgia/arthritis & $43 \%, 13 \%$ & $34 \%$ \\
Cutan vasculitis & $3 \%$ & $18 \%$ \\
Heliotrop rash & $70 \%$ & $50 \%$ \\
ILD & $13 \%$ & $14 \%$ \\
Dysphagia & $36 \%$ & $10 \%$ \\
\hline
\end{tabular}

szakirodalomban leírtaknak. Adatainkat más kutatócsoportokéval hasonlítottuk össze, az eredményeket a 2. és 3. táblázatok tartalmazzák $[6,9,10,11,12]$.

A laboratóriumi eredmények tekintetében azt tapasztaltuk, hogy a betegség kezdetén mért kreatinkináz $(\mathrm{p}=0,005)$, laktátdehidrogenáz $(\mathrm{p}=0,000)$, glutamátoxálecetsav-transzamináz ( $\mathrm{p}=0,054)$, vörösvértest-sülylyedés $(\mathrm{p}=0,044)$ és C-reaktív protein szintje $(\mathrm{p}=0,001)$ mind szignifikánsan magasabbnak bizonyultak felnőtt korú betegeink körében, mint JDM-ben. A csoportok közti különbségeknek az lehet az oka, hogy a felnőttek izomtömege nagyobb és esetükben a gyulladásos folyamatok nagyobb enzimkiáramlással járnak. Az általunk kapott eredmények a laboratóriumi értékek tekintetében is korrelálnak a korábbi irodalmi adatokkal, amelyeket a 4. és 5. táblázat mutat be $[11,12,13]$.

A szerológiai jellegzetességek vizsgálata során nem kaptunk szignifikáns különbségeket a két betegcsoport között, amelynek oka a kis betegszám lehet. Az eredményeink azonban azt mutatják, hogy felnőttkori DM-es betegek körében több MSA-t és MAA-t tudtunk kimutatni. Ez szintén megfelel a nemzetközi irodalmi adatoknak $[14,15,16]$. A gyermekek és felnőttek esetében más-más autoantitest-pozitivitásokat találtunk. Feltehetőleg ezeket a különbségeket a gyermekeket érő eltérő környezeti triggerek, illetve az ugyanarra a triggerre adott eltérő reakció okozhatja. A myositist indukáló kül- 
Bohan és Peter kritériumrendszere alapján készült vizsgálatok pozitivitása JDM-ben

\begin{tabular}{llllll}
\hline & CK & LDH & We & EMG & Biopszia \\
\hline $\begin{array}{l}\text { Saját } \\
\text { adatok } \\
(\mathrm{n}=27)\end{array}$ & $44 \%$ & $33 \%$ & $18 \%$ & $25 \%$ & $55 \%$ \\
$\begin{array}{l}\text { Pachman } \\
(\mathrm{n}=79)\end{array}$ & $64 \%$ & $80 \%$ & - & $81 \%$ & $80 \%$ \\
$\begin{array}{l}\text { Shehata } \\
(\mathrm{n}=25)\end{array}$ & $48 \%$ & $68 \%$ & $88 \%$ & $50 \%$ & $64 \%$ \\
\hline
\end{tabular}

5. táblázat | A felnőttkori DM-ben szenvedő betegek vizsgálatainak pozitivitása a diagnosztikus kritériumrendszer szerint

\begin{tabular}{llllll}
\hline & CK & LDH & GOT & EMG & Biopszia \\
\hline $\begin{array}{l}\text { Saját adatok } \\
(\mathrm{n}=30)\end{array}$ & $83 \%$ & $80 \%$ & $23 \%$ & $73 \%$ & $73 \%$ \\
$\begin{array}{l}\text { Louthrenoo } \\
(\mathrm{n}=100)\end{array}$ & $87 \%$ & $92 \%$ & $82 \%$ & $76 \%$ & $77 \%$ \\
\hline
\end{tabular}

6. táblázat | A DM lefolyása során alkalmazott gyógyszerek

\begin{tabular}{lccc}
\hline & $\begin{array}{c}\text { Juvenilis } \\
\mathrm{DM}\end{array}$ & $\begin{array}{c}\text { Felnőttkori } \\
\mathrm{DM}\end{array}$ & $\begin{array}{c}\text { Szignifikanciaérték } \\
(\mathrm{p})\end{array}$ \\
\hline Betegek száma & 27 & 30 & \\
Methylprednisonol & 25 & 30 & $\mathrm{p}=0,212$ \\
Azathioprin & 6 & 5 & $\mathrm{p}=0,688$ \\
Methotrexat & 11 & 7 & $\mathrm{p}=0,136$ \\
Cyclosporin A & 13 & 6 & $p=0,020$ \\
Cyclophosphamid & 2 & 6 & $\mathrm{p}=0,263$ \\
$\begin{array}{l}\text { Intravénás } \\
\text { immunglobulin }\end{array}$ & 10 & 4 & $p=0,059$ \\
(IVIG) & & & \\
\hline
\end{tabular}

ső környezeti tényező (virális vagy toxikus) szintén különböző lehet, de az is elképzelhető, hogy a felnőttkorban, illetve gyermekkorban jelentkező DM-es betegek genetikai prediszpozíciója más és más $[17,18]$.

A terápia vizsgálata során leggyakrabban alkalmazott készítmény a kortikoszteroid volt, amely az első választandó szer a myositis kezelésében. Azonban gyermekkorú betegeinknél gondolnunk kell a szteroidok hosszú távú mellékhatásaira (például növekedésbeli elmaradás, Cushing-szindróma stb.), emiatt mihamarabb próbálunk szteroidot spórolni és/vagy váltani egyéb másodvonalbeli gyógyszerre. Ezek közül szignifikánsan gyakrabban került sor cyclosporin A és intravénás immunglobulinok alkalmazására juvenilis DM-es betegeink körében (6. és 7. táblázat). Azt is megvizsgáltuk, hogy mely szerektől várhattuk a komplett remisszió elérését. Gyermek betegeink több mint egyharmadának remisszióba kerülése az IVIG-től volt várható, míg a felnőtt betegek közel 50\%ában a terápiás sikert a kortikoszteroidok hozták meg.
7. táblázat $\mid$ A DM lefolyása során komplett remisszió eléréséhez használt gyógyszerek százalékos előfordulása

\begin{tabular}{|c|c|c|}
\hline & Juvenilis DM & Felnőttkori DM \\
\hline Betegek száma & 27 & 30 \\
\hline Methylprednisolon & $15 \%(4 / 27)$ & $\begin{array}{c}50 \% \\
(15 / 30)\end{array}$ \\
\hline Azathioprin & $7 \%(2 / 27)$ & $10 \%(3 / 30)$ \\
\hline Methotrexat & $19 \%(5 / 27)$ & $10 \%(3 / 30)$ \\
\hline Cyclosporin A & $22 \%(6 / 27)$ & $10 \%(3 / 30)$ \\
\hline Cyclophosphamid & 0 & $10 \%(3 / 30)$ \\
\hline $\begin{array}{l}\text { Intravénás } \\
\text { immunglobulin } \\
\text { (IVIG) }\end{array}$ & $\begin{array}{c}37 \% \\
(10 / 27)\end{array}$ & $13 \%(4 / 30)$ \\
\hline
\end{tabular}

8. táblázat |Az egyes kórlefolyástípusok vizsgálata

\begin{tabular}{lccc}
\hline & $\begin{array}{c}\text { Juvenilis DM } \\
(\text { fó) }\end{array}$ & $\begin{array}{c}\text { Felnőttkori } \\
\text { DM (fó) }\end{array}$ & $\begin{array}{c}\text { Szignifikanciaérték } \\
(\mathrm{p})\end{array}$ \\
\hline Betegek száma & 27 & 30 & \\
$\begin{array}{l}\text { Monofázisos-akut } \\
\text { Monofázisos- }\end{array}$ & 1 & 11 & $p=0,003$ \\
$\begin{array}{l}\text { szubakut } \\
\text { Polifázisos }\end{array}$ & 9 & 5 & $\mathrm{p}=0,127$ \\
$\begin{array}{l}\text { Krónikus } \\
\text { progresszív }\end{array}$ & 10 & 10 & $\mathrm{p}=0,702$ \\
\hline
\end{tabular}

9. táblázat |A relapsusok jelentkezése a terápia viszonylatában

\begin{tabular}{lccc}
\hline & $\begin{array}{c}\text { Juvenilis } \\
\mathrm{DM}\end{array}$ & $\begin{array}{c}\text { Felnőttkori } \\
\mathrm{DM}\end{array}$ & $\begin{array}{c}\text { Szignifikanciaérték } \\
(\mathrm{p})\end{array}$ \\
\hline $\begin{array}{l}\text { Betegek száma } \\
\begin{array}{l}\text { Kezdeti terápia } \\
\text { leépítése alatt }\end{array}\end{array}$ & 27 & 30 & $\mathrm{p}=1,000$ \\
$\begin{array}{l}\text { Fenntartó kezelés } \\
\text { alatt }\end{array}$ & 12 & 11 & $p=0,487$ \\
$\begin{array}{l}\text { Fenntartó terápia } \\
\text { leépítése alatt }\end{array}$ & 1 & 0 & $\mathrm{p}=0,466$ \\
$\begin{array}{l}\text { Gyógyszer } \\
\text { elhagyásakor } \\
\text { (kezelés nélkül) }\end{array}$ & 8 & 3 & $p=0,053$
\end{tabular}

A kórlefolyás vizsgálata azt mutatta, hogy felnőttkori dermatomyositises betegek között a monofázisos-akut betegséglefolyás szignifikánsan gyakrabban fordult elö (8. táblázat). Gyermekekben a tünetek fokozatosan jelentkeztek. A betegek gondozása során megfigyeltük, hogy a relapsusok a terápia viszonylatában mikor jelentkeztek. Nos, leggyakrabban a fenntartó kezelés alatt számíthattunk a relapsusok jelentkezésére mindkét betegcsoportban. Azonban a gyógyszeres kezelés elhagyása szignifikánsan megemelte a relapsusok számát juvenilis dermatomyositises betegeink körében (9. táblázat). 


\section{Megbeszélés}

Gyermekkorban az idiopathiás inflammatorikus myopathiák közül leggyakrabban a dermatomyositis fordul elö. A JDM bőrtünetei hasonlóak a felnőttkori formában láthatóakhoz, de bizonyos bőrtünetek, például a napfénynek kitett területeken vagy a feszítő felszíneken jelentkező erythema gyakoribb, mint felnőttek esetében. A betegség klasszikusan a bőrtünetekkel kezdődik [19]. A felnőttkori DM-mel szemben gyakoribb a calcinosis cutis kialakulása [20]. A legjellemzőbb tünetek a betegségre nézve a Gottron-jel (az ízületek feszítőfelszínén megjelenő, hámló jellegű lilás-vöröses macula oedemával vagy a nélkül), a Gottron-papula (vörhenyes papulák a kéz MCP- és PIP-ízületei felett), heliotrop rash (periorbitalis erythema a szemhéjakon, amelyekhez gyakran társul oedema, és a felső szemhéj gyakrabban érintett, mint az alsó) (1-4. ábra). Kutatásunknak megfelelően, mi is hasonló eredményeket találtunk.

Fontosnak tartom kiemelni azt a tényt, hogy a nemzetközi szakirodalomban kevés, szinte alig található olyan közlemény, amely egyszerre tárgyalja a juvenilis és felnőttkori DM teljes klinikumát, ezért is látható az, hogy a tüneteket, illetve a diagnosztikus kritériumokat tekintve csupán különböző paramétereket találtunk. Ennek tükrében a 2-3., valamint 4-5. táblázatok nem vonhatóak össze. Tehát Pachman és Shehata csak a juvenilis DM-es betegek klinikumát vizsgálta, Koh pedig csak a felnőttekét.

A terápia vizsgálata során sokszor merül fel az a kérdés, hogy miért a cyclosporin A és az intravénás immunglobulinok alkalmazása került előtérbe. Juvenilis DM-es páciensek körében a cyclosporin A rendkívül kedvezően hat a bőrtünetekre, továbbá nem citosztatikum, amely kedvező tulajdonság gyermek betegeink körében. A biológiai terápia részeként, az IVIG-ek hatékony szerek DM kezelésére, mind gyermek-, mind felnőttkorban, azonban nagy hátrányuk, hogy drága gyógyszerek, terápiás dózisuk pedig 1-2 g/ttkg. A gyakorlatban a gyermekek testtömege kevesebb, mint a felnőtt betegeké, ezért alkalmazásuk szélesebb körben terjedt el JDM-ben klinikánkon.

A kezelés viszonylatában jelentkező relapsusok a fenntartó terápia ideje alatt alakultak ki leggyakrabban, amelynek az lehet az oka, hogy ekkor azt a minimális dózist próbáljuk beállítani a betegeknél, amelynél a tüne-

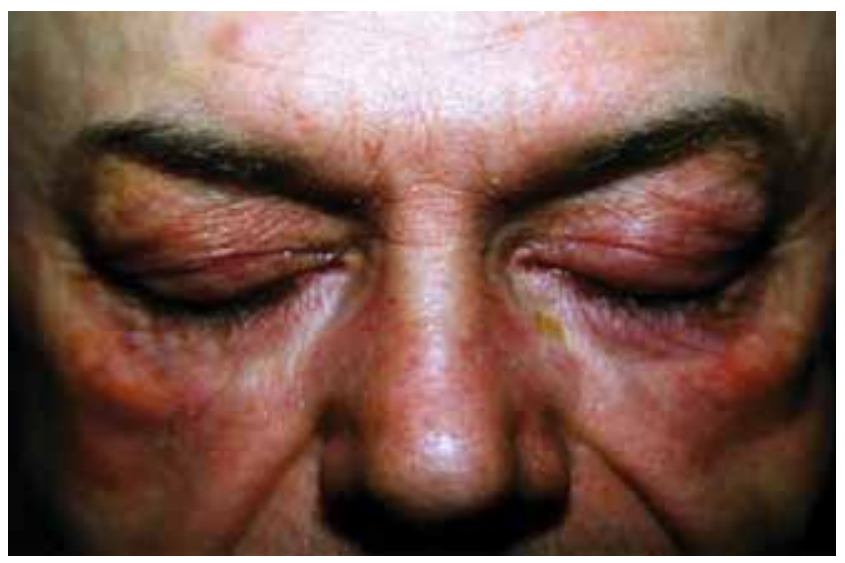

3. ábra

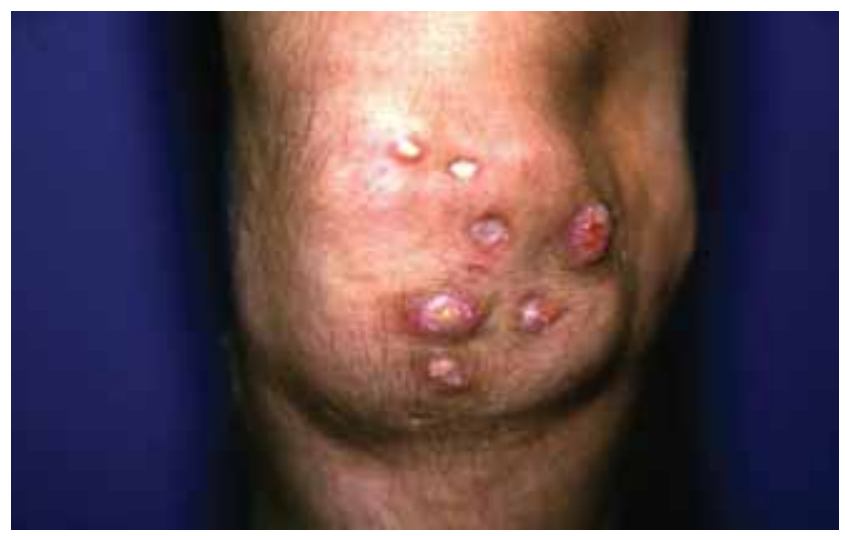

4. ábra | Calcin

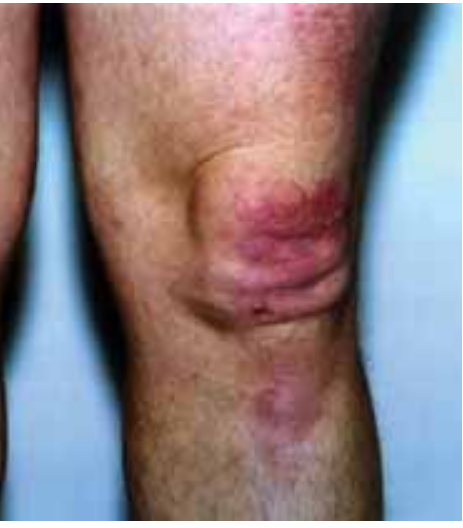


tek reaktiválódása még éppen nem jelentkezik. Ezt a dózisküszöböt nehéz pontosan meghatározni, egyéni különbségeket mutat. Ha pedig relapsus jelentkezik, akkor magasabbra kell emelni a fenntartó dózist. A két betegcsoport között különbséget találtunk annak tekintetében, hogy a relapsusok a JDM-es páciensek esetében a gyógyszer elhagyása során jelentkeztek. Az anamnézisek alapján ezen esetek mind a rossz betegcompliance-szel álltak összefüggésben, azaz önkényes gyógyszerelhagyás történt.

\section{Következtetések}

A Debreceni Egyetem, Klinikai Központ, Belgyógyászati Intézet által gondozott, dermatomyositisben szenvedő gyermekek és felnőttek demográfiai, klinikai, laboratóriumi és immunszerológiai jellemzői különbözőek. Eredményeink megfelelnek a szakirodalomban leírtaknak. Myositises betegeink vizsgálata során átfogó képet kaptunk a juvenilis és felnőttkori dermatomyositisek sajátságainak, betegségkezdetének és lefolyásának különbségeirôl. Ezekre azért fontos nagy hangsúlyt fektetünk, mert a betegség korai felismerésében és a megfelelő terápia megválasztásában segít, ha ismerjük a két betegcsoport különbözőségét. Az időben elkezdett adekvát kezeléssel javíthatjuk a betegek életminőségét, megakadályozhatjuk az akut izomkárosodást és a hoszszú távú szervi károsodások (például: ízületi contracturák) kialakulását. Betegeink rendszeres gondozása a remisszió elérése után is szükséges - elkerülve ezzel a rossz betegcompliance- $t$-, ezáltal csökkenthető a relapsusok száma és súlyossága.

Anyagi támogatás: Sz. O. publikációt megalapozó kutatása az Európai Unió és Magyarország támogatásával, az Európai Szociális alap társfinanszírozásával a TÁMOP 4.2.4.A/2-11-1-2012-0001 azonosító számú „Nemzeti Kiválóság Program - Hazai hallgatói, illetve kutatói személyi támogatást biztosító rendszer kidolgozása és múködtetése konvergenciaprogram" címú kiemelt projekt keretei között valósult meg.

Szerzöi munkamegosztás: Sz. O., N.-V. M.: Adatgyüjtés, klinikai vizsgálatok, statisztikai elemzés, a kézirat elkészítése, szakirodalom-kutatás. D. K.: Adatgyúijtés, klinikai vizsgálatok, adatelemzés. F. F.: Adatgyújtés, szakirodalom-kutatás. A cikk végleges változatát valamennyi szerző elolvasta és jóváhagyta.

Érdekeltségek: A szerzőknek nincsenek érdekeltségeik.

A képek a DE KK Belgyógyászati Intézet Klinikai Immunológiai Tanszékének Myositis Munkacsoportja által készített képadatbázisból származnak. A betegek a képek közléséhez hozzájárultak.

\section{Irodalom}

[1] Lundberg, I., Chung, L. Y.: Treatment and investigation of idiopathic inflammatory myopathies. Rheumatology, 2000, 39(1), 7-17.

[2] Lundberg, I. E., Vencovsky, J., Alexanderson, H.: Therapy of myositis: biological and physical. Curr. Opin. Reumatol., 2014, 26(6), 704-711.

[3] Gowdie, P.J., Allen, R. C., Kornberg, A. J., et al.: Clinical features and disease course of patients with juvenile dermatomyositis. Int. J. Rheum. Dis., 2013, 16(5), 561-567.

[4] Bohan, A., Peter, J. B.: Polymyositis and dermatomyositis (first of two parts). N. Engl. J. Med., 1975, 292(7), 344-347.

[5] Bohan, A., Peter, J. B.: Polymyositis and dermatomyositis (second of two parts). N. Engl. J. Med., 1975, 292(8), 403-407.

[6] Koh, E. T., Seow, A., Ong, B., et al.: Adult onset polymyositis/dermatomyositis: clinical and laboratory features and treatment response in 75 patients. Ann. Rheum. Dis., 1993, 52(12), 857-861.

[7] Targoff, I. N.: Autoantibodies in polymyositis. Rheum. Dis. Clin. North Am., 1992, 18(2), 455-482.

[8] Sibilia, J., Chatelus, E., Meyer, A., et al.: How can we diagnose and better understand inflammatory myopathies? The usefulness of auto-antibodies. Presse Med., 2010, 39(10), 1010-1025.

[9] Tan, J. A., Roberts-Thomson, P. J., Blumbergs, P., et al.: Incidence and prevalence of idiopathic inflammatory myopathies in South Australia: a 30-year epidemiologic study of histology-proven cases. Int. J. Rheum. Dis., 2013, 16(3), 331-338.

[10] Mendez, E. P., Lipton, R., Ramsey-Goldman, R., et al.: US incidence of juvenile dermatomyositis, 1995-1998: results from the National Institute of Arthritis and Musculoskeletal and Skin Diseases Registry. Arthritis Rheum., 2003, 49(3), 300-305.

[11] Pachman, L. M., Hayford, J. R., Chung, A., et al.: Juvenile dermatomyositis at diagnosis: clinical characteristics of 79 children. J. Rheumatol., 1998, 25(6) 1198-1204.

[12] Shehata, R., al-Mayouf, S., al-Dalaan, A., et al.: Juvenile dermatomyositis: clinical profile and disease course in 25 patients. Clin. Exp. Rheumatol., 1999, 17(1), 115-118.

[13] Louthrenoo, W., Weerayutwattana, N., Lertprasertsuke, N., et al.: Serum muscle enzymes, muscle pathology and clinical muscle weakness: correlation in Thai patients with polymyositis/dermatomyositis. J. Med. Assoc. Thai., 2002, 85(1), 26-32.

[14] Rider, L. G., Miller, F. W., Targoff, I. N., et al.: A broadened spectrum of juvenile myositis. Myositis-specific autoantibodies in children. Arthritis Rheum., 1994, 37(10), 1534-1538.

[15] Tansley, S. L., McHugh, N. J., Wedderburn, L. R.: Adult and juvenile dermatomyositis: are the distinct clinical features explained by our current understanding of serological subgroups and pathogenic mechanisms? Arthritis Res. Ther., 2013, 15(2), 211.

[16] Arnett, F. C., Targoff, I. N., Mimori, T., et al.: Interrelationship of major histocompatibility complex class II alleles and autoantibodies in four ethnic groups with various forms of myositis. Arthritis Rheum., 1996, 39(9), 1507-1518.

[17] West, J. E., Reed, A. M.: Analysis of HLA-DM polymorphism in juvenile dermatomyositis (JDM) patients. Hum. Immunol., 1999, 60(3), 255-258

[18] Pachman, L. M., Liotta-Davis, M. R., Hong, D. K., et al.: TNFalpha-308A allele in juvenile dermatomyositis: association with increased production of tumor necrosis factor alpha, disease duration, and pathologic calcifications. Arthritis Rheum., 2000, 43(10), 2368-2377.

[19] Werth, V. P., Bashir, M., Zhang, W.: Photosensitivity in rheumatic diseases. J. Investig. Dermatol. Symp. Proc., 2004, 9(1), 57-63.

[20] Urganus, A. L., Zhao, Y. D., Pachman, L. M.: Juvenile dermatomyositis calcifications selectively displayed markers of bone formation. Arthritis Rheum., 2009, 61(4), 501-508.

(Szalmás Orsolya dr., Miskolc, Márton bíró u. 2-4., 3534 e-mail: csajos66@hotmail.com) 